\title{
Study of Implementation of Agroforestry System in Cibulao Village, Bogor District, West Java Province
}

\author{
Antonius Eko Sunardi, Qonita Hasna'ul Aini, Muhammad Rizki Aditya, and \\ Sari Viciawati Machdum ${ }^{1}$ \\ University of Indonesia - Indonesia.
}

\begin{abstract}
This study tries to explore how the implementation of the Agroforestry system that is initiated by the Ministry of Forestry. The study took place in Cibulao Village, Bogor District, West Java Province, which is in a forest area. The study approach is carried out qualitatively through in-depth interviews. The Agroforestry system is intended to try to reduce forest conversion and destruction as an alternative to protect the forest and at the same time give people around the forest an opportunity to exploit the economic potential of the forest.
\end{abstract}

Key words: agroforestry, village, rural development

\footnotetext{
${ }^{1}$ Antonius Eko Sunardi, Qonita Hasna'ul Aini, Sari Viciawati Machdum, Department of social welfare science, Social and Political Science of Faculty, and Muhammad Rizki Aditya, Department Fiscal Administration Science, Administration Science Faculty, Indonesia University, Depok, Indonesia. Email: antoniuseko.sunardi@gmail.com
} 


\title{
Studi Implementasi Sistem Agroforestri di Kampung Cibulao, Kabupaten Bogor, Provinsi Jawa Barat
}

\author{
Antonius Eko Sunardi, Qonita Hasna'ul Aini, \\ Muhammad Rizki Aditya, dan Sari Viciawati Machdum
}

\section{Pendahuluan}

Hutan merupakan salah satu sumber utama kehidupan di bumi. Hal ini dikarenakan kemampuan hutan yang dapat menghasilkan asupan oksigen yang sangat dibutuhkan oleh setiap makhluk hidup. Selain sebagai sumber kehidupan bagi setiap mahluk hidup, secara khusus hutan juga memberikan manfaat ekonomis bagi manusia. Sebagai salah satu negara yang berlokasi di kawasan beriklim tropis, Indonesia memiliki kekayaan hutan yang sangat luas dengan potensi sumber daya alam yang sangat berlimpah di dalamnya. Pada tahun 2015 sebanyak 120.773.441,71 Ha wilayah daratan Indonesia merupakan kawasan hutan (KLHK, 2017). Seiring dengan perkembangan waktu, diperkirakan luas Hutan di Indonesia terus mengalami penyusutan yang merupakan akibat dari adanya penebangan hutan, pembakaran hutan, eksploitasi, dan alih fungsi kawasan hutan sebagai kawasan perumahan. Sebagai negara yang memiliki wilayah hutan yang sangat luas, seharusnya Indonesia dapat mempertahankan kelestarian wilayah hutannya, terutama karena masyarakat Indonesia masih banyak yang menggantungkan hidupnya dari hutan.

Kementerian Kehutanan Republik Indonesia mencatat sedikitnya 1,1 juta hektar atau 2\% dari luas wilayah hutan Indonesia menyusut setiap tahun. Kerusakan hutan di Indonesia ini tercatat sebagai kerusakan hutan yang kelima terbesar di dunia, sebagaimana dilansir oleh Global Forest Watch dalam laman resminya. Kerusakan hutan yang terjadi di Indonesia dalam kurun waktu antara tahun 2001 hingga 2016 diperkirakan sebesar 23,09 juta hektar (Global Forest Watch, 2017). Penyusutan wilayah hutan ini seharusnya dibarengi dengan peningkatan pertumbuhan ekonomi negara karena penyusutan hutan yang terjadi mayoritas beralasan untuk kemajuan ekonomi seperti pendirian industri, membangun infrastruktur, membangun perumahan, dan sebagainya. Ironis melihat kenyataan yang ada bahwa "pertumbuhan ekonomi" hanya berlaku bagi sebagian golongan, yakni golongan menengah ke atas. Kemajuan ekonomi yang terjadi tidak menyentuh lapisan masyarakat menengah ke bawah. Badan Pusat Statistik (2014) menggunakan ukuran tingkat kesejahteraan 
dengan indeks kemiskinan multidimensi yang mencakup pendidikan, kesehatan, dan standar hidup (Dewan Kehutanan Nasional, 2017) melaporkan bahwa jumlah rumah tangga dengan sumber pendapatan utama dari subsektor kehutanan yang tergolong miskin multidimensi adalah 35,7 persen, paling besar dibanding subsektor lainnya. Desa hutan umumnya terletak jauh dari perkotaan, dan hanya memiliki infrastruktur jalan, penerangan, air bersih, kesehatan, dan pendidikan yang serba terbatas. Bahkan akses mereka ke hutan pun sangat terbatas, yang mengakibatkan sebagian dari mereka mengaksesnya secara ilegal. Mengentaskan kemiskinan dan meningkatkan kesejahteraan masyarakat desa hutan tidak terlepas dari upaya memperbesar akses mereka terhadap sumber daya alam di sekitarnya, yang selama ini masih banyak masyarakat desa hutan yang mengaksesnya secara ilegal.

Penelitian ini akan membahas tentang penerapan sistem agroforestri sebagai solusi mengatasi masalah ekonomi masyarakat menengah ke bawah, yakni dengan memberdayakan masyarakat setempat untuk melakukan kegiatan yang bernilai ekonomis di wilayah hutan dengan tetap menjaga kelestarian hutan itu sendiri. Agroforestri, sebagaimana yang didefinisikan oleh lembaga penelitian agroforestri internasional (ICRAF = International Centre for Research in Agroforestry) adalah suatu sistem penggunaan lahan yang mengkombinasikan tanaman berkayu (pepohonan, perdu, bambu, rotan dan lainnya) dengan tanaman tidak berkayu atau dapat pula dengan rerumputan (pasture), kadang-kadang ada komponen ternak atau hewan lainnya (lebah, ikan) sehingga terbentuk interaksi ekologis dan ekonomis antara tanaman berkayu dengan komponen lainnya. Tujuan digunakannya elemen tanaman tidak berkayu ataupun hewan adalah untuk dimanfaatkan hasilnya, seperti buah-buahan, akar, getah tanaman, hingga susu, madu, telur, dan daging hewan yang kemudian dapat dijual dan menjadi penghasilan bagi petani atau peternak yang merupakan masyarakat kelas menengah ke bawah yang berada di sekitar hutan.

Memanfaatkan potensi sumber daya hutan dengan menggunakan sistem agroforestri dapat menjadi langkah awal pemberdayaan ekonomi masyarakat yang baik. Pemberdayaan ekonomi rakyat sendiri adalah usaha untuk menjadikan ekonomi yang kuat, besar, modern, dan berdaya saing tinggi dalam mekanisme pasar yang benar. Karena kendala pengembangan ekonomi rakyat adalah kendala struktural, maka pemberdayaan ekonomi rakyat harus dilakukan melalui perubahan struktural. Perubahan struktural yang dimaksud adalah perubahan dari ekonomi tradisional ke ekonomi modern, dari ekonomi lemah ke ekonomi kuat, dari ekonomi 
subsisten ke ekonomi pasar, dan/atau dari ketergantungan ke kemandirian. Langkahlangkah proses perubahan struktural meliputi: pengalokasian sumber pemberdayaan sumberdaya, penguatan kelembagaan, penguasaan teknologi, dan pemberdayaan sumber daya manusia. (Sumodiningrat dalam Mardi Yatmo Hutomo, 2000:6)

Lebih lanjut Sumodiningrat menjelaskan bahwa pemberdayaan ekonomi masyarakat tidak cukup hanya dengan meningkatkan produktivitas, memberikan kesempatan berusaha yang sama, dan hanya memberikan suntikan modal sebagai stumulan, tetapi harus dijamin adanya kerjasama dan kemitraan yang erat antara wilayah yang telah maju dengan yang masih lemah dan belum berkembang. Kebijakan dalam pembedayaan ekonomi rakyat yang umum dijumpai yaitu pemberian peluang atau akses yang lebih besar kepada aset produksi (khususnya modal), memperkuat posisi transaksi dan kemitraan usaha ekonomi rakyat, agar pelaku ekonomi rakyat bukan sekadar price taker, pelayanan pendidikan dan kesehatan, penguatan industri kecil, mendorong munculnya wirausaha baru, dan pemerataan spasial. Kegiatan pemberdayaan masyarakat mencakup: peningkatan akses bantuan modal usaha, peningkatan akses pengembangan SDM, dan peningkatan akses ke sarana dan prasarana yang mendukung langsung sosial ekonomi masyarakat lokal.

Salah satu daerah yang sudah mulai menerapkan sistem argoforestri adalah Kampung Cibulao, Desa Tugu Utara, Kabupaten Bogor, Jawa Barat. Berdasarkan kriteria yang diberikan oleh Kementerian Percepatan Pembangunan Kawasan Tertinggal (2004), Kampung Cibulao tergolong sebagai daerah tertinggal karena memenuhi 4 dari 5 kriteria yang ada, yakni: 1) sumber daya alam yang ada memiliki potensi fisik yang besar, namun daerah belum cukup berkembang karena kondisi geografis yang sulit terjangkau. Penguasaan dan penerapan teknologi relatif rendah karena adanya keterbatasan dukungan sarana dan prasarana teknologi; 2) Keterbatasan sarana prasarana komunikasi, transportasi, layanan kesehatan, pendidikan, dan layanan lainnya sehingga penduduk daerah yang bersangkutan sulit untuk melakukan aktivitas ekonomi maupun sosial; 3) Rendahnya akses ke daerah pusat pertumbuhan sehingga biaya transportasi menjadi sangat tinggi; 4) Daerah sulit dijangkau. Wilayah tertinggal sendiri dapat didefinisikan sebagai suatu wilayah yang relatif kurang berkembang dibandingkan wilayah lainnya dalam skala nasional berdasarkan kondisi dan fungsi interspasial maupun intraspasial baik pada aspek alam, manusia, maupun sarana dan prasarana pendukung. (Bappenas, 2005). 
Menyadari kekurangan yang ada di daerahnya, pemerintah melalui BUMN yang dalam hal ini adalah Perhutani bekerja sama dengan warga Kampung Cibulao melalui KTH Hijau Cibulao untuk mengembangkan wilayah Kampung Cibulao dengan memanfaatkan sumber daya alam yang ada. Terletak di wilayah yang jauh dari pusat kegiatan ekonomi, jalan raya, dan berdekatan dengan hutan, warga Kampung Cibulao memanfaatkan tanaman kopi untuk ditanam dan dibudidayakan di hutan kaki Gunung Gede Pangrango untuk kemudian dipetik bijinya dan diolah hingga menjadi minuman kopi. Olahan biji kopi ini pun mampu mendatangkan penghasilan yang cukup untuk meningkatkan perekonomian masyarakat setempat, mengingat popularitas kopi yang sedang naik daun yang diiringi dengan menjamurnya kedai-kedai kopi. Pada tahun 2016, salah satu varietas kopi Cibulao jenis robusta mulai dikenalkan pada masyarakat luas dengan mengikuti kompetisi tingkat nasional. Dari hasil kompetisi ini, kopi jenis Robusta dari Kampung Cibulao mendapatkan predikat sebagai Kopi Robusta terbaik di Indonesia. Hal ini membuat permintaan terhadap kopi Cibulao semakin meningkat, yang berimplikasi pada melonjaknya harga jual dari kopi Cibulao itu sendiri.

Maka dari itu, penulis memilih Kampung Cibulao sebagai tempat penelitian ini. Melalui penelitian ini, penulis ingin melihat bagaimana penerapan sistem argorestri dalam upaya pemberdayaan perekonomian masyarakat di Kampung Cibulao. Penelitian ini diharapkan dapat bermanfaat untuk memperluas studi mengenai argoforestri dan penerapannya di Indonesia, serta menjadi sumber acuan dalam pengembangan ilmu pengetahuan mengenai pemanfaatan hutan dan pemberdayaan ekonomi. Juga untuk menciptakan kesadaran akan pentingnya mempertahankan kelestarian lingkungan dalam melakukan kegiatan ekonomi.

\section{Metode Penelitian}

Dalam penelitian ini pendekatan yang digunakan adalah pendekatan kualitatif yang bertujuan untuk memberikan gambaran terperinci serta menjelaskan rangkaian tahapan atau langkah (Neuman, 2013). Teknik yang digunakan dalam pengumpulan data primer yaitu melalui wawancara, observasi dan dokumentasi. Pihak yang menjadi informan dalam penelitian ini ditentukan dengan menggunakan teknik purposive sampling, sehingga informan penelitian dipilih berdasarkan informasi yang dibutuhkan terkait dengan topik penelitian (Neuman, 2014). Informasi yang akan diperoleh dalam penelitian ini adalah terkait penerapan sistem 
agroforestri sebagai upaya pemberdayaan ekonomi pada masyarakat di Kampung Cibulao. Sehingga informan dalam penelitian ini adalah warga masyarakat Kampung Cibulao yang diwakilkan oleh KTH Hijau Cibulao dan pihak Perhutani. Data yang dapat mendukung penelitian didokumentasikan melalui foto dan video. Jumlah seluruh informan dalam penelitian ini adalah delapan informan.

\section{Hasil dan Pembahasan}

Masyarakat di Kampung Cibulao merupakan masyarakat yang hidup dan tinggal dengan memanfaatkan hutan yang berada di sekitar Kampung Cibulao. Letak Kampung Cibulao yang berada di kaki Gunung Gede Pangrango membuat masyarakat menggantungkan kehidupannya pada hutan yang ada di wilayah tersebut. Hal ini terlihat dari banyaknya kebutuhan hidup masyarakat yang dapat diperoleh dari hutan seperti kayu untuk kebutuhan bahan bakar untuk memasakmaupun untuk kebutuhan pembangunan rumah masyarakat. Pemenuhan akan kebutuhan tersebut telah mendorong masyarakat untuk melakukan penebangan hutan secara bebas tanpa memperhatikan kelestarian hutan. Masih banyak dari masyarakat yang belum menyadari bahwa kegiatan penebangan hutan yang dilakukan dapat menimbulkan bencana seperti tanah longsor ataupun banjir.

Meskipun sebagian besar masyarakat dari Kampung Cibulao masih belum peduli terhadap kelestarian hutan di wilayah Kampung Cibulao, namun terdapat sebagian kecil masyarakat Kampung Cibulao yang memiliki kepedulian terhadap hutan dengan membentuk kelompok pecinta alam untuk menjaga kelestarian hutan di wilayah tersebut. Masyarakat yang tergabung dalam kelompok pecinta alam tersebut kemudian melakukan berbagai kegiatan-kegiatan untuk menjaga kelestarian hutan seperti kegiatan penanaman pohon. Dalam rangka menghindari kegagalan program penanaman pohon akibat penebangan yang dilakukan oleh masyarakat, maka kelompok pencinta alam Kampung Cibulao memilih untuk menanam tanaman kopi yang dianggap lebih produktif. Tanaman kopi dapat hidup dan menghasilkan biji kopi dalam jangka waktu yang cukup lama sehingga masyarakat Kampung Cibulao dapat memperoleh manfaat dari tanaman kopi tersebut dalam jangka waktu yang lama pula tanpa harus menebang pohon. Keberadaan tanaman kopi yang memiliki nilai ekonomis ini mampu menekan perilaku penebangan hutan yang dilakukan oleh masyarakat Kampung Cibulao. Hal ini karena pohon-pohon disekitar tanaman kopi tersebut apabila ditebang 
sudah pasti akan mengenai tanaman kopi yang di tanam berdampingan dengan pohon lainnya. Keberadaan pepohonan hutan disekitar tanaman kopi memiliki fungsi sebagai pelindung bagi tanaman kopi. Sistem penanaman kopi yang mengkombinasikan antara pohon kopi sebagai tanaman utama dan pepohonan hutan sebagai tanaman pelindung inilah yang dikenal sebagai sistem agroforestri. Melalui sistem agroforestri tersebut, masyarakat Kampung Cibulao dapat memanfaatkan lahan hutan secara produktif tanpa harus merusak ekosistem hutan tersebut.

\subsection{Penerapan Sistem Agroforestri di Wilayah Kampung Cibulao}

Sistem agroforestri merupakan suatu sistem penggunaan lahan terpadu, yang mengkombinasikan antara aspek ekologi dan aspek sosial. Sistem ini akan mengkombinasikan pepohonan dengan tanaman pertanian dan/atau ternak (hewan), baik secara bersama-sama ataupun bergiliran, sehingga dari satu unit lahan tercapai hasil yang baik dan berkesinambungan (Nair, 1993). Pengelolaan lahan melalui sistem argoforestri ini juga menerapkan teknik pengelolaan praktis yang sesuai dengan budaya masyarakat setempat untuk meningkatkan produksi lahan secara berkelanjutan yang terdiri dari kombinasi produksi tanaman pertanian dengan tanaman hutan dan/atau hewan secara berasama atau bergiliran (K.F.S. King \& M.T. Chandler, 1979). Secara sederhana sistem agroforestri dapat dilihat sebagai perpaduan antara komponen tanaman berkayu atau kehutanan dengan tanaman pertanian dan/atau peternakan, yang dilakukan secara bersama-sama ataupun bergilir dengan tujuan untuk mendapatkan manfaat yang optimal. Kampung Cibulao, Desa Tugu Utara, Kabupaten Bogor merupakan salah satu wilayah yang berhasil menerapkan sistem agroforestri dalam upaya untuk mengembangkan potensi hutan yang ada di wilayahnya tanpa harus melakukan perusakan terhadap hutan itu sendiri. Penerapan sistem agroforestri terlihat dari pengkombinasian antara pepohonan endemik hutan dengan tanaman kopi yang memiliki nilai ekonomis. Pepohonan endemik hutan di wilayah Kampung Cibulao merupakan pepohonan berkayu seperti Rasamala, Puspa, Sinenten, Damar serta Sengon. Sedangkan pemilihan tanaman kopi sebagai tanaman utama bermula dari salah satu seorang tokoh masyarakat yang biasa di panggil 'Emak' yang membawa bibit kopi dari Temanggung untuk dikembangkan di wilayah Kampung Cibulao. Emak bersama dengan pecinta alam di wilayah Kampung Cibulao berusaha mengembangkan kopi sebagai komoditas utama di wilayah Kampung Cibulao. 
Hal ini kemudian menjadi sumber penghasilan bagi masyarakat Kampung Cibulao. Dalam mengembangkan sistem penanaman kopi, Emak dan kelompok pecinta alam di Kampung Cibulao juga memperhatikan karakteristik wilayah hutan tersebut sehingga dapat pula memberikan manfaat bagi pelestarian hutan. Berkembangkan tanaman kopi pada lahan hutan di Kampung Cibulao tersebut kemudian dikelola oleh Kelompok Tani Hutan Cibulao Hijau (KTH Cibulao Hijau) yang beranggotakan Emak dan kelompok pecinta alam Kampung Cibulao tersebut. Melalui KTH Cibulao Hijau tersebut, penanaman kopi dengan sistem agroforestri di Kampung Cibulao semakin berkembang. KTH Cibulao Hijau memperhatikan setiap prosedur penanaman kopi seperti jarak antar masing-masing pohon dan penyiangan lahan selama 2 bulan untuk mensterilkan tanah dari zat-zat beracun sebelum melakukan penanaman kopi, prosedur perawatan tanaman kopi dengan pemangkasan pucuk pohon, serta memperhatikan pola penanaman dengan model terasering untuk mengurangi pengikisan tanah oleh air hujan. Hal ini bertujuan untuk memperoleh hasil kopi berkualitas dan keseimbangan ekosistem hutan.

Dalam mengembangkan sistem agroforestri untuk budidaya kopi di wilayah Kampung Cibulao, KTH Hijau Cibulao menjalin kerjasama dengan Perhutani sebagai salah satu Badan Usaha Milik Negara (BUMN) sebagai pemilik lahan hutan yang bertanggung jawab untuk menjamin fungsi dan manfaat hutan bagi kesejahteraan masyarakat dan kelestarian hutan. Pada awalnya masyarakat Kampung Cibulao menggunakan lahan milik Perhutani secara sembunyi-sembunyi, tapi setelah mendapat izin dari Perhutani melalui mekanisme Pengelolaan Hutan Bersama Masyarakat (PHBM). Hal tersebut membuat masyarakat Kampung Cibulao leluasa untuk menanam kopi di wilayah hutan Perhutani dengan catatan bahwa setiap masyarakat yang ingin memanfaatkan lahan hutan hanya boleh menggunakan lahan hutan dengan tegakan dibawah 60\%. Melalui kerjasama ini diharapkan masyarakat menjadi lebih bertanggung jawab terhadap kelestarian hutan. Selanjutnya terkait pembagian hasil hutan, KTH Hijau Cibulao memperoleh $80 \%$ hasil hutan sedangkan Perhutani memperoleh 20\% dari hasil hutan. 


\subsection{Sistem Agroforestri Sebagai Pemberdayaan Ekonomi Masyarakat Kampung Cibulao}

Pemberdayaan ekonomi merupakan sebuah penguatan akan kepemilikan faktor produksi, penguatan penguasaan, penguatan proses distribusi dan pemasaran, penguatan masyarakat untuk mendapatkan hasil yang memadai dan penguatan masyarakat untuk memperoleh pengetahuan, informasi, dan keterampilan yang harus didapatkan secara multi aspek, baik dari aspek masyarakatnya sendiri, maupun dari aspek kebijakannya (Hutomo, 2000). Pembangunan ekonomi masyarakat juga dipandang sebagai agenda utama pembangunan nasional di Indonesia terutama bagi wilayah-wilayah yang termasuk dalam wilayah yang tertinggal dan terluar, sehingga langkah-langkah nyata perlu diupayakan untuk mendorong percepatan ekonomi masyarakat (Swasono dalam Rintuh, Cornelis, dan Miar, 2005). Secara umum, tujuan dari adanya pemberdayaan masyarakat adalah untuk meningkatkan taraf hidup masyarakat yang pada dasarnya meliputi: kebutuhan hidup, kebutuhan harga diri, dan kebutuhan akan kebebasan (Goulet dalam Suryana, 2006).

Kampung Cibulao yang masuk kedalam empat dari lima kriteria yang ditetapkan oleh Kementerian Percepatan Pembangunan Kawasan Tertinggal (2004) yakni: 1) sumber daya alam yang ada memiliki potensi fisik yang besar, namun daerah belum cukup berkembang karena kondisi geografis yang sulit terjangkau. Penguasaan dan penerapan teknologi relatif rendah karena adanya keterbatasan dukungan sarana dan prasarana teknologi; 2) Keterbatasan sarana prasarana komunikasi, transportasi, layanan kesehatan, pendidikan, dan layanan lainnya sehingga penduduk daerah yang bersangkutan sulit untuk melakukan aktivitas ekonomi maupun sosial;3) Rendahnya akses ke daerah pusat pertumbuhan sehingga biaya transportasi menjadi sangat tinggi; 4) Daerah sulit dijangkaudirasa sangat perlu untuk bisa mengembangkan perekonomian mereka untuk mengejar ketertinggalan dari daerah-daerah lain di sekitarnya, terutama karena Kampung Cibulao memiliki potensi alam yang sangat melimpah dan masih belum dapat dikembangkan dengan maksimal.

Melalui KTH Hijau Cibulao masyarakat Kampung Cibulao telah berhasil melakukan bentuk pemberdayaan ekonomi masyarakat dengan melakukan penguatan pada faktor produksi, penguatan distribusi dan pemasaran dari produk utama mereka yaitu Kopi Khas Cibulao yang saat ini sudah banyak dikenal oleh banyak orang. Pemberdayaan ekonomi yang dilakukan oleh KTH Hijau Cibulao dilakukan dengan memanfaatkan sistem agroforestri untuk memaksimalkan komoditas utama 
kopi khas Cibulao.

Sistem agroforestri merupakan sistem yang memungkinkanbeberapa komponen yang berbeda saling berinteraksi dalam satu sistem (pohon, tanaman, dan/atau ternak). Kondisi tersebut membuat sistem ini memiliki karakteristik yang sangat unik dalam hal jenis produk, waktu untuk memperoleh produk dan orientasi penggunaan produk. Dengan demikian karakteristik agroforestri yang sedemikian ini sangat mempengaruhi fungsi sosial-ekonomi dari penerapan sistem agroforestri itu sendiri (Hairiah, dkk., 2013).

Keunikan dan karakteristik khusus yang dimiliki dari sistem Agroforestri ini yang membuat kopi khas Cibulao memiliki rasa yang khas dan berbeda dibandingkan dengan kopi yang berasal dari tempat lain karena kopi khas Cibulao ditanama berdampingan dengan pohon hutan sebagai pelindung dan pohon lain seperti kayu manis dan alpukat yang menambah cita rasa kopi khas Cibulao.

Ketekunan dalam pemeliharaan tanaman kopi oleh KTH Hijau Cibulao mulai dari penentuan letak penanaman, penyiangan tanah dari zat beracun, mekanisme pemetikan hingga pengolahannya ini berhasil mengantarkan kopi khas dari Kampung Cibulao untuk memperoleh pengakuan sebagai kopi jenis robusta terbaik tingkat nasional melalui ajang Kontes Kopi Spesialti Indonesia (KKSI) ke VII yang berlangsung di Gayo, Aceh pada tahun 2017. Keberhasilan sebagai kopi terbaik dalam kontes tersebut telah mempopulerkan Kopi Khas Cibulao. Dengan semakin meningkatkanya minat masyarakat umum kepada kopi khas Cibulao ini telah mendorong KTH Hijau Cibulao untuk semakin memperluas pasar kopi Cibulao secara offline dengan mendistribusikannya melalui kedaikedai kopi di sekitar Bogor maupun secara online melalui media sosial. Kopi khas Cibulao memiliki nilai ekonomis yang cukup bersaing dengan kopi dari daerah lainnya. Untuk kopi jenis robusta Cibulao dihargai Rp 30.000,00 per 100 gram, sedangkan untuk kopi arabika Cibulao dihargai Rp 50.000,00 per 100 gram. Sebelum adanya KTH Cibulao Hijau dan teknik penanaman kopi yang baik, harga kopi Cibulao dikendalikan oleh tengkulak dengan dibawah pasaran yaitu sebesar Rp 25.000,00 per kilogram. Dengan demikian keberadaan KTH Cibulao Hijau dan teknik penanaman kopi dengan sistem agroforestri telah meningkatkan harga jual kopi Cibulao sekaligus meningkatkan perekonomian masyarakat.

Disamping pemasaran produk kopi, KTH Hijau Cibulao juga mengembangkan kampung wisata edukasi kopi yang bertujuan untuk mengenalkan 
kopi khas Cibulao kepada masyarakat umum dengan memberikan pemahaman bagaimana proses penanaman kopi melalui sistem agroforestri di Kampung Cibulao. Selain menawarkan edukasi tentang pembuatan kopi Cibulao, KTH Hijau Cibulao juga mengajak masyarakat luar untuk merasakan suasana menginap di Kampung Cibulao dan melestarikan lingkungan melalui kegiatan penanaman pohon. Kampung wisata edukasi kopi ini juga menjadi roda penggerak perekonomian masyarakat Kampung Cibulao. Hal ini terlihat dari pelibatan seluruh masyarakat Kampung Cibulao sebagai tour guide, penyewaan homestay hingga penyedia jasa boga bagi para wisatawan.

\section{IV.Kesimpulan}

Masyarakat Kampung Cibulao yang hidup berdampingan dengan hutan milik Perhutani masih memanfaatkan lahan hutan sebagi sumber perekonomian. Dalam memanfaatkan lahan hutan, masyarakat Kampung Cibulao menerapkan sistem agroforesteri sebagai sistem pengelolaan lahan hutan. Penerapan sistem agroforestri di Kampung Cibulao terlihat dari pengkombinasian pepohonan endemik hutan dengan tanaman kopi yang dikelola oleh KTH Cibulao Hijau. Kombinasi tanaman kopi dengan pepohoan endemik hutan ini menghasilkan karakteristik unik pada citarasa kopi sehingga kopi khas Cibulao dapat memperoleh predikat kopi robusta terbaik dalam Kontes Kopi Spesialti Indonesia (KKSI) ke VII. Hal tersebut membuat kopi khas Cibulao menjadi popular dan banyak diminati oleh masyarakat luas hingga pemasaran produk kopi khas Cibulao semakin luas. Melalui pemasaran produk kopi khas Cibulao tersebut, perekonomian masyarakat Kampung Cibulao dapat meningkat. Disamping itu, keunikan penanaman kopi khas Cibulao dengan sistem agroforestri juga menjadi potensi wisata edukasi bagi masyarakat luas. Potensi wisata tersebut diwujudkan dalam kampung wisata edukasi kopi Cibulao yang melibatkan seluruh masyarakat Kampung Cibulao sebagai tour guide, penyewaan homestay, dan penyedia jasa boga bagi para wisatawan. Hal ini menjadi sumber pendapatan bagi masyarakat Kampung Cibulao. Dengan demikian penerapan sistem agroforestri untuk budidaya kopi di Kampung Cibulao telah meningkatkan perekonomian masyarakat Kampung Cibulao dengan tetap menjaga kelestarian hutan. 


\section{Referensi}

BPS dalam Dewan Kehutanan Nasional. (2017). Kesejahteraan Masyarakat Pinggiran Hutan. Dewan Kehutanan Nasional.

Hairiah, dkk. (2003). Pengantar Argoforestri: Bahan Ajar I. Bogor: World Argoforestry Center (ICRAF).

Hutomo, Mardi Yatmo. (2000). Pemberdayaan Masyarakat dalam Bidang Ekonomi. Yogyakarta: Adiyana Press.

Kementerian Lingkungan Hidup dan Kehutanan. (2015). Statistik Kementerian Lingkungan Hidup dan Kehutanan 2015. Kementerian Lingkungan Hidup dan Kehutanan.

King, KFS. (1979). Agroforestry. Proceeding of the Fiftieth Symposium on Tropical Agriculture. Royal Tropical Institute, Amsterdam, The Netherlands.

Nair, PKR. (1993). An Introduction to Agroforestry. Kluwer Academic Publisher, The Netherlands. 499.

Neuman, W.L. (2013). Social Research Methods: Qualitative and Quantitative Approaches. London: Pearson.

Neuman, W.L. (2014). Social Research Methods: Qualitative and Quantitative Approaches. United States of America: Pearson Education Limited.

Rintuh, Cornelis dan Miar. (2005). Kelembagaan dan Ekonomi Rakyat. Yogyakarta. BPFE.

Ristania, Amilda. (2007). Identifikasi Keterkaitan Pusat Pertumbuhan Di Kabupaten Garut Bagian Selatan Sebagai Wilayah Tertinggal. Bandung: Institut Teknologi Bandung.

Suryana. 2006. Ekonomi Pembangunan: Problematika dan Pendekatan. Jakarta. Salemba Empat.

Watch, Global Forest. (2017). Countries with Greatest Tree Cover Loss. Global Forest Watch. 